\title{
Blasts 20-30 Percent of Peripheral Blood White Cells
}

National Cancer Institute

\section{Source}

National Cancer Institute. Blasts 20-30 Percent of Peripheral Blood White Cells. NCI

Thesaurus. Code C150452.

A semi-quantitative microscopic finding indicating that between 20 and 30 percent of the nucleated cells in a peripheral leukocyte sample are immature mononuclear cells. 